\title{
EFL Teachers' Productive Skills Errors and their Effects on Students' English Language Proficiency: The Case of Selected Preparatory Schools in East Wollega Zone
}

\author{
Tamiru Olana* and Zeleke Teshome*
}

Institute of Language Studies and Journalism, Wollega University, Post Box No: 395, Nekemte, Ethiopia

\begin{tabular}{|c|c|}
\hline Abstract & \\
\hline \multirow{16}{*}{$\begin{array}{l}\text { The objective of this descriptive study was to investigate the types of oral and written errors } \\
\text { EFL teachers make, the sources of the errors and their potential effects on students' English } \\
\text { language proficiency. Qualitative and quantitative data were collected from } 16 \text { teachers } \\
\text { found in } 4 \text { preparatory schools in East Wollega Zone. The schools were selected purposively } \\
\text { according to their locations and the teachers were selected by availability sampling } \\
\text { technique. To get the quantitative and the qualitative data on the types of written and the oral } \\
\text { errors, essays and interviews were used. The sources and effects of the written and oral } \\
\text { errors were found through classroom observations, dictation of English words and interview. } \\
\text { The written errors were grouped as grammatical, lexical, semantics and mechanics, and the } \\
\text { oral ones were grouped as grammatical, lexical and semantic. The findings indicated that the } \\
\text { teacher-participants made } 380 \text { written errors which occurred in } 19 \text { categories } 360 \text { oral errors } \\
\text { which occurred in } 16 \text { categories. The analysis of the interview data attributed sources of the } \\
\text { teachers' written errors to the grammatical, lexical, semantics and mechanics errors made as } \\
\text { intralingual transfer. From the dictation of } 30 \text { English words made by the researchers, it was } \\
\text { found out that the teacher-participants' primary school experiences had an interlanguage } \\
\text { error transfer on them such that their spelling errors were due to a lack of appropriate } \\
\text { pronunciation teaching by their primary and secondary school teachers. The other source of } \\
\text { teachers' written errors was the mismatch between their English language learning } \\
\text { experiences with their current teaching experiences. The findings also indicated that the fact } \\
\text { that teachers made oral and written errors undeservedly, posed problems on their students' } \\
\text { language proficiency. Thus, it could be concluded that the targeted teachers need lots of } \\
\text { trainings and workshops not to let them spoil their students' language proficiency. }\end{array}$} & e History: \\
\hline & Received : 06-10-2015 \\
\hline & : 17-12-2015 \\
\hline & Accepted : 19-12-2015 \\
\hline & \\
\hline & \\
\hline & kills \\
\hline & icy \\
\hline & al \\
\hline & Intrali \\
\hline & oonding Author: \\
\hline & ad \\
\hline & Zeleke les \\
\hline & E-mail: \\
\hline & \\
\hline & \\
\hline
\end{tabular}

\section{INTRODUCTION}

Much has been said with regard to the determinants of students' English language proficiency without stressing teachers' English language productive skills errors as contributing factors to students' limited English language proficiency. Research conducted in this area suggests that teachers' professional experience, that is, their language education, training background, and their experience as teachers, can influence their implementation or non- implementation of what they are expected to. For example, some teachers add articles or otherwise where they are not necessary or omit them where they are necessary.

A local study similar to the title under discussion was conducted by Yoseph Mekonnen (1990). He found out that 111 out of 577 errors identified from 908 exchanges amounting to $19.2 \%$ were errors in the use of articles. He further noted that eliminating article errors would reduce $19.2 \%$ of the EFL teachers' errors and this, he says, will surely contribute to the improvement of their being model of English to the students. Eliminating these article errors, he says, would give the teachers a $19.2 \%$ error-free performance in the classroom. In the same research, he reported that teachers' English language also suffers from many pronunciation errors resulting from first language interference.

Moreover, Tewolde (1988) in his study noted that teachers that he observed in the junior secondary schools made serious errors, the most frequent ones of which were the misuse of tenses and mistakes in subject-verb agreement. His comment, which is not much different from other similar studies, was that the weakness of the teachers in expressing themselves orally accurately can have a great effect on the students' understanding of the language because if it is not clearly expressed, it cannot be clearly understood (ibid).

Therefore, the above local studies focused merely on one of the productive skills, i.e., speaking skills whereas the focus of the present research is on both speaking and writing skills errors teachers make. Besides, it investigates the types and sources of errors teachers make and their effects on students' English language proficiency. 
Tamiru Olana and Zeleke Teshome

\section{Types of Errors}

There are three terms which overlap one another when we talk about the 'what' and 'where' of error analysis. These terms are types of errors (Richards, 1992), sources of errors (Brown, 2007) and causes of errors (Norrish, 1990). Though demarcations have not been made to identify these terminologies, attempts have been made to indicate each based on the existing literature.

In a second/foreign language learning, two major types of errors from the analysis of oral and written performances were defined. The first is intralingual/ developmental error which reflects not only the structure of the mother tongue, but also over-generalizes based on partial exposure to the target language. Overgeneralization involves the creation of one deviant structure in place of two regular structures, for example, 'He can sings', "We are hope", "it is occurs". The second one is interlingual errors. Selinker (1974) referred the negative interference from the learner's first language habits. For example, many EFL learners think in their first language and use direct translation when they speak and write in FL. According to Ellis (1994), there are different types of errors based on the surface strategy; namely, omission, addition, semantic errors, word order errors, sentence fragments and subject-verb agreement errors.

Omission error is one of the characteristics of L2 errors in general and of Ethiopian learners of English in particular. Omission errors are characterized by the absence of an item that must appear in a well-formed utterance (Dulay et al., 1982). The other one is addition errors which are characterized by the presence of an item which must not appear in a well-formed utterance. He added that addition errors indicate some basic rules have been acquired but the refinements have not yet been made. Semantic error is a spelling or typing or selecting error that turns an intended word into another word of the target language. Errors identified in the section are a matter of lexical choice. For the most part, they are the result of relating L2 words to already learned L2 words. This is to say errors which are made when the students get confused about lexical items that are usually categorized as relational opposites (Laufer, 1997). Word order errors are characterized by the incorrect placement of a morpheme or group of morphemes in an utterance. Disordering errors occur systematically for both L2 and L1 learners in constructions that have already been acquired. A sentence fragment is a word group that is attempting to function as a sentence but lacking independent clause. In some circumstances, they can be easy to notice, but when placed in related sentences, it can become more difficult. Some fragments are incomplete because they lack either a subject or a verb or both. Subject-verb agreement is a grammatical rule that states that the verb must agree in number with its subject. According to Greenbaum and Nelson (2002), the verb agrees with its subject in number and person. On the other hand, Huddleston and Pullum (2007) mention that subject-verb agreement involves person as well as number, for $1^{\text {st }}$ person $I$, although singular, requires eat, not eats.

\section{Sources of Language Teachers Errors}

Teachers' ability to write well is one of the essential qualities in the world of academics and other concerns of life. Yet, it is a difficult skill to master for them because of different factors pertaining to it. Scholars raise these
Sci. Technol. Arts Res. J., Oct-Dec 2015, 4(4): 164-173

factors as prior language learning experiences and language teachers' teaching experiences. The next sections show the detail.

\section{a. Prior Language Learning Experiences}

The influence of prior language learning experiences of language teachers on their knowledge of teaching and practices has been recently recognized in various studies in second language education and applied linguistics (Borg, 2003; Freeman and Johnson, 1998; Meijer et al., 2001; Peacock, 2001). For instance, Borg states that teachers' prior language learning experiences establish cognitions about language learning which form the basis of their initial conceptualizations of L2 teaching during teacher education, and which may continue to be influential throughout their professional lives.

Meijer et al. (1999) regarded prior experiences as part of the teachers' background variables that potentially affect teachers' practical knowledge. Ulichny (1996) explains that since teachers' beliefs about their students and learning are formed by their prior language learning and teaching experiences, these beliefs structure 'the knowledge base' for teaching. Breen et al. (2001) also argue that teachers' classroom work is highly influenced by their prior experiences starting from their early school age.

Golombek (1998) made a similar observation in her study on college ESL teachers' personal practical knowledge and discussed how teachers' language learning experiences have affected their classroom practices. In her study, one of the ESL teachers recalled one of those moments when her teacher corrected her mistakes while she was trying to speak: "I could talk like anything, but when he started to check my grammar... I became terrified speaking in his class because I know that I was going to be corrected..." ( $p, 454)$. As she would not want her students to live through the same painful experiences, she adopted a reverse strategy: "I just [...] I wouldn't want somebody doing that to me, so I can't do that I guess" ( $p, 454)$ and applied it to her own teaching.

\section{b. Language Teachers' Teaching Experiences}

The second source of influence on teachers' knowledge is their experience as professionals. A Spanish teacher in Moran's (1996) study described how she reflected upon her experience as a Spanish language learner in her practice and how she was influenced by her teaching experience with the help of her students' reactions to it. All these experiences resulted in changes in her classroom instruction. Consistent with this example, an ESL teacher in Ulichny's (1996) study also reported on how her prior experience as an ESL teacher was as significant as her educational beliefs in her classroom practices.

The brief discussion of this group of studies has shown that the teachers have been influenced to some extent by their prior experiences as language learners as well as their experiences as second/foreign language teachers. These accumulated experiences, whether they are positive or negative, help the teachers shape their classroom instruction. Whatever the case maybe, the logical problem of language learning is caused by teachers' messy and fragmentary proficiency, making abstract concepts based on less proficiency and inappropriate usage of language skills that might affect 
Tamiru Olana and Zeleke Teshome

the quality of students' language proficiency (Mitchell and Myles, 2004).

One of the most pertinent theories informing this study is that of Krashen (1985) who reported that the essential ingredient for L2 acquisition is comprehensible proficiency through teacher talk. The teacher should talk on a learner's level of comprehension, that is, the learner should be able to understand what the teacher is saying (Richards and Lockhart, 1994). When teachers' own L2 knowledge is not on an acceptable standard for the use of English, their poor usage and knowledge of the language are transferred to the learners (Nel and Muller (2010). Therefore, in the context of this paper, teachers are responsible for students' inadequate language proficiency due to their own limited English proficiency.

\section{MATERIALS AND METHODS}

This descriptive study demanded the collection of both qualitative and quantitative data. The data from teachers' written essays and from classroom observation comprised the quantitative component of the design and teachers' interview the quantitative and qualitative components. Creswell's (2007) "dominant-less-dominant model" was used, whereby a small component is drawn from the alternative method (qualitative) and is included in the dominant method, in this case, the quantitative method of data analysis. The components from the quantitative data comprised examples of teachers' English language errors and used as a triangulation method to substantiate the findings in the qualitative component of the study. It was also be served to answer the "How" part of the research question.

The researchers examined the contents of the essays and the dictations made to identify the types of teachers' written errors. These errors were compared and analyzed to determine how the teachers' oral and written English language errors influence their students' productive skills proficiency. Based on the data collected, the researchers followed the route described by Nel and Muller (2010) who identified substantial similarities in portfolios which led to the conclusion that teachers' L2 forms are transferred to their ESL learners' language forms and reflect the teachers' poor productive English language proficiency.

\section{Sampling Techniques}

Four preparatory schools (Nekemte, Arjo Gudetu, Gidda and Sire) were selected purposively on the basis of their location (central, west, north and east respectively) in the zone. Four sections from each school that are taught by different English language teachers were selected. The selection of the teachers was employed based on availability sampling including all EFL teachers teaching at the 4 schools. Accordingly, 16 teachers participated in writing essay and all of them showed their willingness for the classroom observation.

\section{Instruments of Data Collection}

The major instruments used in this research were classroom observation, document analysis (teachers' essay writing), dictation and teachers' interview.

Oral activities like teachers' input, oral feedback, and teachers' and students' interactions were observed two
Sci. Technol. Arts Res. J., Oct-Dec 2015, 4(4): 164-173

times each in one section. To this effect, the 16 teachers, who teach the selected sections, were observed two times each. For the observation, checklist was prepared and used to curiously identify the types and sources of teachers' productive skills errors and how the errors affect students' English productive skills proficiency.

Teachers' essays were analyzed to identify the types of written errors each make and whether and how the written teachers' errors affect students' English language proficiency. Besides, the researchers' field notes were analyzed to explore the sources of English teachers' productive skills errors that affect students' English proficiency skills.

The researchers made informal observation and identified that the targeted teachers make spelling errors when they write on the blackboard. Believing that dictating the subjects with some English words might indicate some more errors, the researchers purposively selected 30 English words from grades 11 and 12 English textbooks and grouped them in different pronunciation categories.

All the 16 teachers in the selected schools participated in the interview as their number was manageable for interview. The purpose of using teacher interview is to cross-check whether they confirm orally or not what was actually be seen in the classroom.

\section{Analysis Strategy}

Since majority of the data from the responses of the teacher-participants were categorical in nature, a nonparametric analysis strategy, in which descriptive statistics such as frequency tables and percentage were discussed. To determine the effects of EFL teachers' productive skills errors on their students' English language proficiency, comparison of categories and data triangulations were computed. Parts of the qualitative data that were gathered through classroom observation and teacher interview were coded, organized and analyzed, and then combined with the quantitative data for the final discussion.

\section{RESULTS AND DISCUSSION}

In this study, the steps of error analysis as specified by Corder (1987) were followed. First, essays written by teachers were examined word by word and sentence by sentence. The researchers generated the coding categories based on all written and oral samples of teachers. Second, they counted the number of errors and converted them into frequency and percentage to examine the occurrence. In Step 2 and 3 in Table 1, they listed different types of errors. All errors were underlined and labeled.

After analyzing the type of errors, the researchers recognized the causes of teachers' oral and written errors. Each researcher independently reviewed the writing and oral samples of both parties for common categories. The researchers then met to present their interpretations and arrived at a shared understanding of the coding. Categories were compared for similarities, differences, and connections. Once the categories had been reexamined to determine how they were connected, the data were presented and clustered into common units of meaning or theme. 
Table 1: Steps to Analyze Teachers' Written and Oral Errors

\begin{tabular}{|c|c|c|c|}
\hline Steps & Procedures & Definitions of steps & Examples \\
\hline Step 1 & Collect data & $\begin{array}{l}\text { Written and oral data from } \\
\text { teachers }\end{array}$ & Teachers, $N=16$ \\
\hline Step 2 & Identify errors & $\begin{array}{l}\text { Different types of teachers' } \\
\text { written errors }\end{array}$ & $\begin{array}{l}\text { articles, number, adjectives, relative clause, verb tense, } \\
\text { nouns, pronouns, tense, preposition, run-on, verb } \\
\text { formation, subject-verb agreement, fragment } \\
\text { pronunciation; Word choice; Meaning; Mechanics }\end{array}$ \\
\hline Step 3 & $\begin{array}{l}\text { Classify } \\
\text { errors }\end{array}$ & $\begin{array}{l}\text { Is it an error of verb, } \\
\text { agreement, tense, etc.? }\end{array}$ & $\begin{array}{l}\text { Grammatical, lexical, semantic, mechanics } \\
\text { pronunciation errors }\end{array}$ \\
\hline Step 4 & $\begin{array}{l}\text { Analyze error } \\
\text { sources }\end{array}$ & Sources of errors & $\begin{array}{l}\text { Intralingual (developmental errors) } \\
\text { Interlingual (interference errors) }\end{array}$ \\
\hline Step 5 & $\begin{array}{l}\text { Analyze } \\
\text { Effects }\end{array}$ & $\begin{array}{l}\text { What are the effects of } \\
\text { teachers' errors on } \\
\text { students' productive skills } \\
\text { proficiency? }\end{array}$ & $\begin{array}{l}\text { Samples of teachers' oral and written errors affected } \\
\text { students' English productive skills proficiency }\end{array}$ \\
\hline
\end{tabular}

The results of the study are based on the three research questions posed. The answers to the first question focused on categories of grammatical error types, frequency of occurrence of each error, percentage of each error out of the total errors made.

\section{Types of EFL Teachers' Productive Skills Written Errors}

\section{Types of Written Errors Made by EFL Teachers}

To gather the data on teachers' written errors, the researchers requested the teachers to write an essay of their interest in the researchers' presence so that they might not copy from other written materials. The errors and their corrections were tabulated in Table 2.

In Table 2 above, the teacher-participants made grammatical, lexical, semantics and mechanics written errors $f=380(100 \%)$. Among the types of teachers' written errors identified, grammatical $f=207(54.5 \%)$, lexical $f=104(27.3 \%)$, semantics $f=12(3.3 \%)$ and mechanics $f=$ $61(16.1 \%)$ were occurred in 19 categories. Among these errors, grammatical errors were occurred in 10 categories, lexical in 5 categories, semantics in 1 category and mechanics in 3 categories.

Table 2: Analysis of Types of Teachers' Written Errors $(N=16)$

\begin{tabular}{|c|c|c|c|c|c|c|}
\hline \multirow{2}{*}{ No } & \multirow{2}{*}{ Error Types } & \multirow{2}{*}{ Error Categories } & \multirow{2}{*}{$\mathbf{F}$} & \multirow{2}{*}{$\%$} & \multicolumn{2}{|c|}{ Examples } \\
\hline & & & & & Wrong & Correct \\
\hline \multirow{11}{*}{1} & \multirow{10}{*}{ Grammar } & S-V agreement & 38 & 10 & \multirow{10}{*}{$\begin{array}{l}\text { It encourage smokers } \\
\text { Many school } \\
\text { Such as according to the } \\
\text { qualification of--- } \\
\text { You will losing your life } \\
\text { So that } \\
\text { Wait I will read it for you } \\
\text { They still smoking } \\
\text { People who lives.... } \\
\text { I do not have no idea } \\
\text { How we can stop } \\
\text { smoking? }\end{array}$} & It encourages smokers \\
\hline & & Number & 32 & 8.4 & & Many schools \\
\hline & & $\begin{array}{l}\text { Sentence } \\
\text { structure }\end{array}$ & 30 & 7.9 & & According to the qualification of... \\
\hline & & Verb tense & 28 & 7.4 & & You will lose your life \\
\hline & & Coordination & 16 & 4.2 & & In fact \\
\hline & & Run-on & 15 & 3.9 & & Wait. I will read it for you \\
\hline & & Verb omission & 14 & 3.7 & & They are still smoking \\
\hline & & Relative clause & 12 & 3.2 & & People who live.... \\
\hline & & Double negative & 12 & 3.2 & & I do not have any idea \\
\hline & & Word order & 10 & 2.6 & & How can we stop smoking? \\
\hline & & Total & 207 & 54.5 & & \\
\hline \multirow{6}{*}{2} & \multirow{6}{*}{ Lexis } & Article & 35 & 9.2 & $\mathrm{He}$ is best student & $\mathrm{He}$ is the best student \\
\hline & & Preposition & 24 & 6.3 & In the time of exams & During exams \\
\hline & & Pronoun & 20 & 5.3 & My colleague and myself & My colleague and I \\
\hline & & Adjective & 15 & 3.9 & It is a little book. & It is a small book. \\
\hline & & Adverb & 10 & 2.6 & In generally & In general \\
\hline & & Total & 104 & 27.3 & & \\
\hline 3 & Semantics & Word choice & 8 & 2.1 & You should coordinate & You should collaborate \\
\hline \multirow{5}{*}{4} & \multirow{4}{*}{ Mechanics } & Capitalization & 20 & 5.3 & it is one.... & It is one.... \\
\hline & & Spelling & 14 & 3.7 & her adress & her address \\
\hline & & Punctuation & 27 & 7.1 & However & However, \\
\hline & & Total & 61 & 16.1 & & \\
\hline & Grand Total & & 380 & 100 & & \\
\hline
\end{tabular}

From the data it can be inferred that the targeted teachers had the greatest problems $f=38(10 \%)$ in constructing sentences with appropriate subject-verb agreement when compared with other written errors. It also indicated that teachers made many errors in constructing sentences with appropriate singular and plural forms $\mathrm{f}=32(8.4 \%)$, sentence structure errors $\mathrm{f}=30(7.9 \%)$ and verb tense construction errors $\mathrm{f}=$ $28(7.4 \%)$. In categories like coordination, run-on and verb omission, the teachers made almost similar amounts of 


\section{Tamiru Olana and Zeleke Teshome}

grammatical errors $f=16(4.2 \%), \quad f=15(3.9 \%)$ and $\mathrm{f}=14(3.7 \%)$ respectively. Similarly, relative clauses $f=12(3.2 \%)$, double negative $f=12(3.2 \%)$ and word order $\mathrm{f}=10(2.6 \%)$ teachers' written errors hold significant position. the targeted teachers made. Thus, the study indicated that teachers make lots of grammatical errors when they write.

In the same Table, lexical errors $f=104(27.3 \%)$ were also the most frequent errors occurred in 5 categories. The data also indicated that article $\mathrm{f}=35(9.2 \%)$, preposition $f=24(6.3 \%)$, pronoun $f=20(5.3 \%)$, adjective $\mathrm{f}=15(3.9 \%)$ and adverb, $\mathrm{f}=10(2.6 \%)$ were areas in which teachers written errors. Thus, it could be suggested that the targeted teachers had more problems in using appropriate articles, prepositions and pronouns the least problems being in using appropriate adverbs and adjectives.
Sci. Technol. Arts Res. J., Oct-Dec 2015, 4(4): 164-173

The semantics errors teachers made $f=8(2.1 \%)$, were relatively minimal. Even so, the errors were very critical For instance, words such as coordination and collaboration that were exemplified in the table are not synonymous to be used interchangeably. What the writers of this paper inferred was that teachers could make relatively a few errors in both written and oral skills because they have limited vocabulary.

The targeted teachers made mechanics errors $\mathrm{f}=61(16.1 \%)$ under three categories. Among these, punctuation $\mathrm{f}=27(7.1 \%)$, capitalization $\mathrm{f}=20(5.3 \%)$ and spelling $f=14(3.7 \%)$. The data indicated that from these categories, teachers have a great problem in punctuation marks. In the other two categories the teachers also made significant errors.

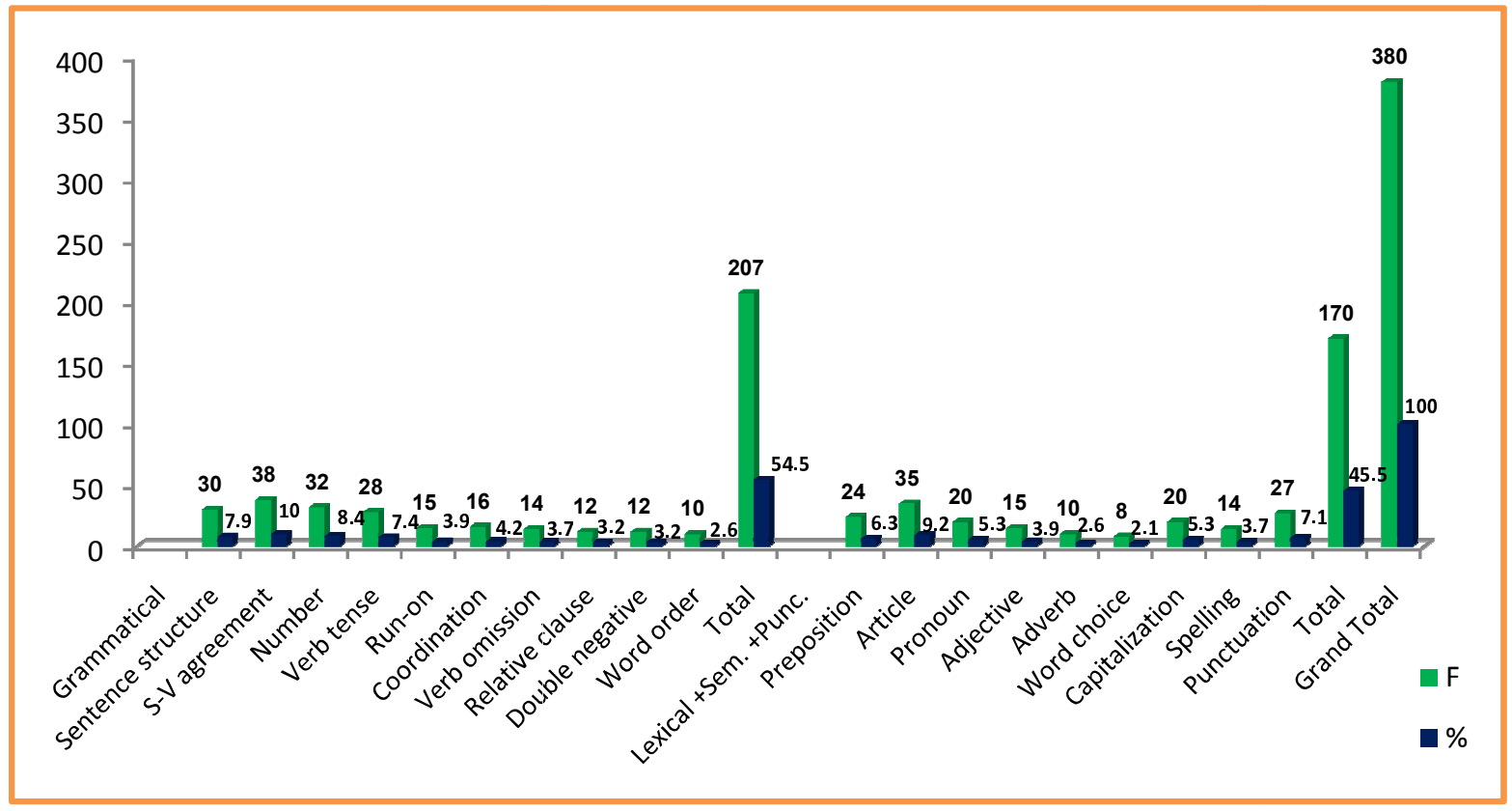

Figure 1: Teachers' Grammatical, Lexical, Semantics and Punctuation Written Errors $(N=16)$

\section{b. Types of Oral Errors Made by Teachers}

To collect data on teachers' oral errors, the researchers designed individual interview and recorded the teachers' speeches. Then, they counted the errors and identified the types and categories of errors made during the discussions. Accordingly, the grammatical and lexical error types occurred in the teachers' speeches were presented in Table 3 below.

In Table 3, the teacher-participants made lots of grammatical, lexical and semantics oral errors $\mathrm{f}=360(100 \%)$. As indicated in the table, grammatical $f=139(38.6 \%)$, lexical $f=209(58.1 \%)$ and semantics $12(3.3 \%)$ oral errors made by the teachers were occurred in 16 categories. Among these, grammatical errors were occurred in 8 categories. The lexical and semantic oral errors were occurred in 7 and 1 categories respectively. This implies that the targeted teachers were educated in deductive method of language teaching which might have made them not to apply the grammatical forms practically in their daily communication.

The data indicated that from the grammatical categories identified, EFL teachers had great problems, $\mathrm{f}=\mathbf{2 8}(7.8 \%)$, in constructing sentences with appropriate subject-verb agreement when compared with other oral grammatical errors made. They also made many errors in constructing sentences with appropriate singular and plural forms $\mathrm{f}=\mathbf{2 5}(6.9 \%)$, sentence structure errors $\mathrm{f}=24(6.7 \%)$ and verb tense construction errors $\mathrm{f}=20(5.6 \%)$. In categories like relative clauses and verb omission, the teachers had minimal variations in the grammatical errors they made $f=12(3.3 \%)$ and $f=10(2.8 \%)$ respectively. Surprisingly, the teachers made nonexistent English word errors $f=4(1.1 \%)$ though the errors were insignificant as compared to other errors. This indicates that though the targeted teachers are not rich in vocabulary, they try to use appropriate English words. 
Table 3: Analysis of Teachers' Oral Errors $(N=16)$

\begin{tabular}{|c|c|c|c|c|c|c|}
\hline \multirow{2}{*}{ No } & \multirow{2}{*}{ Error Types } & \multirow{2}{*}{ Error Categories } & \multirow[b]{2}{*}{$\mathbf{F}$} & \multirow[b]{2}{*}{$\%$} & \multicolumn{2}{|c|}{ Examples } \\
\hline & & & & & Wrong & Correct \\
\hline \multirow{9}{*}{1} & \multirow{8}{*}{ Grammar } & Sentence structure & 24 & 6.7 & Let me I & \multirow{8}{*}{$\begin{array}{l}\text { Let me } \\
\text { A person who flies an... } \\
\text { Support was } \\
\text { Last time, we saw } \\
\text { twenty } \\
\text { Take this but leave that one } \\
\text { Why don't you answer? } \\
\text { people who use condom--- }\end{array}$} \\
\hline & & S-V agreement & 28 & 7.8 & A person who fly an... & \\
\hline & & Number & 25 & 6.9 & Support were & \\
\hline & & Verb tense & 20 & 5.6 & Last time, we have seen & \\
\hline & & Nonexistent & 4 & 1.1 & tweny & \\
\hline & & Coordination & 16 & 4.4 & Take this and leave that one & \\
\hline & & Verb omission & 10 & 2.8 & Why you not answer? & \\
\hline & & Relative clause & 12 & 3.3 & people which use condom- & \\
\hline & \multirow{7}{*}{ Lexis } & Total & 139 & 38.6 & & \\
\hline \multirow{6}{*}{2} & & Preposition & 28 & 7.8 & .teaching since 8 years & \multirow{6}{*}{$\begin{array}{l}\text {...teaching for } 8 \text { years } \\
\text { the rain } \\
\text { Taye has } \\
\text { I advise them. } \\
\text { Girma told me in a brotherly } \\
\text { manner } \\
\text { HIV/AIDS moves fast } \\
\text { /bild/ , /diskıs/, /fa:mə/ }\end{array}$} \\
\hline & & Article & 32 & 8.9 & a rain & \\
\hline & & Verb & 24 & 6.7 & Taye have & \\
\hline & & Pronoun & 10 & 2.8 & I advise they & \\
\hline & & Adjective & 12 & 3.3 & Girma told me brotherly & \\
\hline & & $\begin{array}{l}\text { Adverb } \\
\text { Pronunciation }\end{array}$ & $\begin{array}{l}7 \\
96\end{array}$ & $\begin{array}{l}1.9 \\
26.7\end{array}$ & $\begin{array}{l}\text { HIVIAIDS moves fastly } \\
\text { /build/, /diskəs/,/fa:rmər/ }\end{array}$ & \\
\hline \multirow[t]{3}{*}{3} & Semantics & $\begin{array}{l}\text { Word meaning/ } \\
\text { diction }\end{array}$ & 12 & 3.3 & I'll borrow you my pen & l'll lend you my pen. \\
\hline & & Total & 221 & 61.4 & & \\
\hline & & Grand Total & 360 & 100 & & \\
\hline
\end{tabular}

In the same table, lexical and semantics types of teachers' oral error were identified. The data indicated that among the 7 categories identified under lexical errors, pronunciation holds the greatest share, $f=96(26.7 \%)$, which is the most frequent type of errors made by the teachers. Article errors $\mathrm{f}=32(8.9 \%)$, preposition errors $f=28(7.8 \%)$ and verb errors $f=24(6.7 \%)$, stand from second to fourth in the categories. The other lexical errors like adjective $\mathrm{f}=12(3.3 \%$, pronoun $\mathrm{f}=10(2.8 \%)$ and adverb $\mathrm{f}=7(1.9 \%)$ oral errors were made by the teachers. From the data it could be inferred that the teacher-participants have many problems to pronounce English words intelligibly.
Once more, the data indicated that teachers made considerable word-meaning errors which accounted $\mathrm{f}=12(3.3 \%)$. Thus, the study indicated that teachers had the greatest problems in legibly pronouncing English words when they teach. The distribution of other oral errors also makes us stand and think about the targeted teachers' language proficiency. The researchers could realize that the teacher-participants made a few word meaning errors not because they were very cautious to use the words correctly but because they had a few alternatives in their memory.

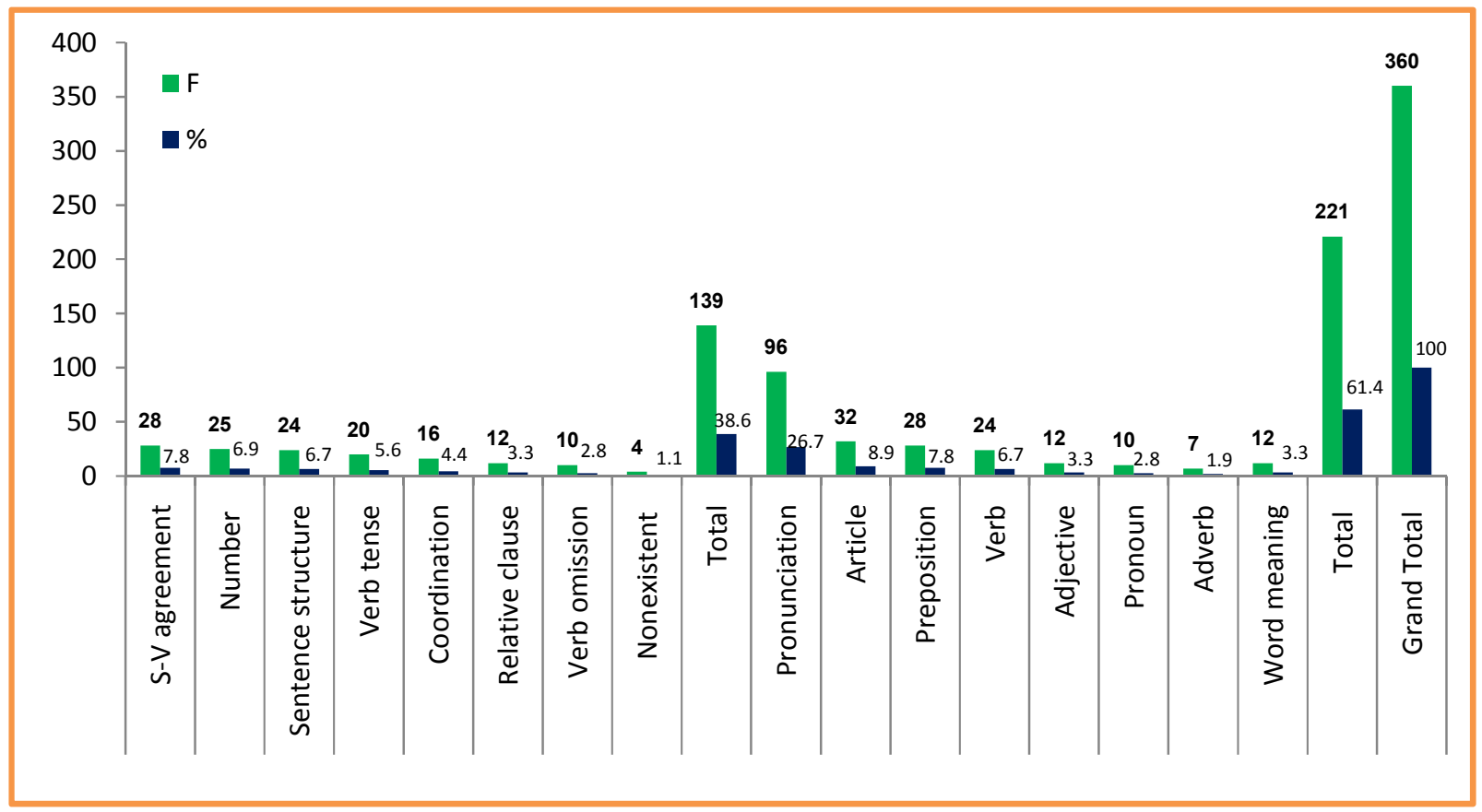

Figure 2: Teachers' Grammatical, Lexical and Semantic Oral Errors $\quad(N=16)$ 
Tamiru Olana and Zeleke Teshome

\section{Sources of EFL Teachers Productive Skills Errors \\ Sources of EFL Teachers Written Errors}

In response to research question two of this study, the researchers used data collected through teachers' interview and dictation on some English words to check whether they are influenced by their mother tongue pronunciation or not. The teachers were asked different questions to tell the potential sources of their written errors. First, they were required to report whether they relate their background of English language learning with their current teaching experiences as sources of their writing skills errors.

One of the teacher-respondents (T1) stated saying, "To tell you the truth, most of our English language teachers were not qualified in English language teaching themselves. As a result, they did not emphasise the writing parts in the textbooks. The teachers used to capitalize on grammar rather than on composition. Therefore, we transit our problems to our students, too." This response was supplemented by T4, T6, T8 and T11.

What the respondents concluded was that, as English teachers, they could not teach writing to their students the ways it should go attributing the inefficiency to the pedagogical mismatch in the teaching of the target language. T5 raised the issue of written yet not pronounced letters in English orthography as problems to both teachers and students. He honestly explained that he makes errors when he writes words like: climb, foreign, autumn, height, kitchen, calm, doubt, etc. from his mind when he is dictated.

T5's justification for the errors he makes is that he listens to the pronunciation of the words and then spells them the way his mother tongue (Afan Oromo) is spelt. Rightly he explained that because there are no silent letters in Afan Oromo, we sometimes partially apply the same rule to the target language and write, for example, as: clim, forein, autm, hight, kichen, cam, dout, etc.

Taking over the speech, T6 added that their students' errors are worse than that of their teachers. He elaborated that if the same dictation is given to the students, they might spell the words exactly as when they write in Afan Oromo. For example, clayim, foren, otm hayit, kichin, kam daut, etc. (T7 and $\mathrm{T} 8$ ) reiterated what $\mathrm{T} 5$ explained. Taking the note of the words T5 listed, the researchers asked respondents in other sites if the same problem of spelling happens in their schools. T1, T3, T14, T16 confirmed that they make errors on similar issues as proposed by T5. From the responses, the researchers could find out that the teachers confuse the spelling of Afan Oromo with the spelling of the target language.

The results of the dictation of words selected from students' textbooks also confirmed what the teachers said. For example, the researchers collected words like dawn, bow, latter, island, biscuit, muscle, handsome and loyalty as /do:n/, /bau/, /la:tə/, /ailænd/, /biskit/, /m^sl/, /hænsəm/, and /loiəti/ respectively. However, most of the respondents spelt the words as down, baw, later, iland, biskit, masil, hansome and loyality respectively. This implies that the teachers have not practiced pronunciation when they were students and have not made any effort to improve their skills of pronunciation as teachers. This deficiency of teachers has become a source of their errors in spelling.
Sci. Technol. Arts Res. J., Oct-Dec 2015, 4(4): 164-173

\section{Sources of EFL Teachers Oral Errors}

Besides the written errors, the teacher- respondents clearly narrated the sources of their oral errors. For example, T1 puts it in the following way:

When I was at elementary school, none of my English teachers taught me how to pronounce English words. As a result, I pronounce English the way I pronounce my Afan Oromo. That is a big problem for all of us today.

In addition, T7 and T9 attribute the problem to their primary school teachers saying that they would like to curse their primary school English language teachers for their not teaching them how to pronounce English words. T2 extends the source of his English words pronunciation errors to his secondary and tertiary levels English language teachers. He put it like this: "I do not blame only primary school English teachers but also secondary and tertiary level teachers. Other teacher-respondents (T3, T10 and T12) also blame EFL teachers at all levels as they did not give significant attention to how intelligible pronunciation can be practiced.

It would be better to stress on what T4 narrated during the interview. She started learning English when she was a grade one student in public school. Thinking back on her own experiences in learning English, she remembered how reserved she was in speaking and how she refrained from using the language even in her university classes. She believed that her limited opportunities and encouragement to practice English in her early years of learning was the reason behind her hesitation in communicating with her current learners. Her perception of her shortcomings was so powerful that she repeatedly commented on them.

T4's limited opportunities to speak English in her prior language learning years also informed her pedagogical decision making and led her to remind her students to practice their oral skills as much as they could. The motive for her was to help them not to live through the same negative language learning experience as she did when she was learning English.

Effects of EFL Teachers' Productive Skills Errors on their Students' English Proficiency

\section{Effects of EFL Teachers' Oral Errors}

During the interview with the EFL teachers, the researchers asked them to explain whether their errors affect their students' language proficiency or not. For this question, one of the interviewees (T6) stated that it is sometimes transferable. For example, "I do remember my primary school teachers' ways of pronouncing some words like tweny instead of twenty." Whereas another teacher-respondent (T9) remembers back what his secondary school teacher, most of the time, was saying supportance instead of support.

During the classroom observation, the researchers identified the oral errors teachers made (which were actually analyzed in Table 4 above) under different error categories. For example, for verb-tense error, they were observed saying last time we have seen made their students follow the same pattern rather than saying last time we saw. Besides, another teacher was observed making sentence structure oral errors like let me I instead of let me which might make students wrongly repeat following his steps. The other error that teachers made 


\section{Tamiru Olana and Zeleke Teshome}

during their lesson presentations was coordination problem. For example, one of the observed teachers said take this and leave that one instead of take this but leave that one, which actually his students did not have other opportunity than repeating their teacher's usage of wrong coordination.

Errors like verb omission, pronoun and diction such as why you not answer?, I advise they and I will borrow you my pen--- instead of Why don't you answer?, I advise them and I will lend you my pen were also respectively made by the teachers. These errors are believed to directly or indirectly affect students' oral English language proficiency. Rephrasing what Krashen (1985) stated about the importance of teacher-talk as an asset for students' language learning, making such bold errors would adversely reverse the outcome. Though English is foreign to both teachers and students, if teachers are not better than their students in avoiding errors, their students' opportunity of getting significant input might be affected.

\section{Effects of EFL Teachers' Written Errors}

To check whether teachers' written errors affect their students' written English language proficiency, the sampled teachers were asked to compose essays of their interest in the presence of the researchers. This was done after the very purpose of the study was explained to the subjects. The teachers were given one and half an hour to write the essays. Then, the researchers collected the essays and identified the following written errors which critically could affect their students' written English proficiency.

The data from the written essays indicated that the most frequently made error types were of number in which one of the subjects, for example, said many school instead of many schools. From such errors, it is very easy to guess that the teacher has problems in numbering which in turn might spoil his students' future appropriate use of numbering. Sentence structure was another transferable written error teachers made. For instance, T3 wrote in his easy, such as according to the quality of--- to mean according to the quality of---. From this error, the researchers could realize that it would be very difficult for the teacher to show his students how appropriate word organization is made. Furthermore, error of verb-tense was observed when one of the teachers wrote sentences such as you will losing your life--- instead of you will lose your life--- which could imply that it would lead students to use wrong verb-tense.

The researchers also observed run-on, verb-omission and double negation written errors made by teachers. For instance, T1 wrote I said wait I will read it for you ---to mean I said, wait. I will read it for you---, they still smoking to mean they are still smoking and I do not have no idea- to mean I do not have any idea---, which could negatively affect students' knowledge of appropriate sentence construction. Still word order was another teachers' written error observed by the researchers in which one of the teachers (T10), constructed a sentence like How we can stop smoking? to mean How can we stop smoking?, which has a potential power to mislead students and let them confuse the knowledge of declarative and interrogative sentence patterns.

Teachers were also seen making grammatical and lexical written errors. For example, one of the teachers
Sci. Technol. Arts Res. J., Oct-Dec 2015, 4(4): 164-173

(T7) made preposition errors such as in the time of exams to mean during exams which actually could lead students to use the same pattern (see Table 2 above). In addition, adverbial written errors like in generally instead of in general which could affect students' writing proficiency were also scrutinized.

Lastly, semantics and mechanics errors were categories given attention to during observations. For example, in the case of diction, T4 wrote you should coordinate instead of you should collaborate whereas in the case of spelling, it was recorded that her adress to mean her address which could lead students to repeat the same semantics and mechanics errors.

\section{DISCUSSION}

This study was designed in part to contribute to the relatively small body of knowledge so far available on the types and sources of productive skills errors teachers make and their effects on students' English language proficiency. The various linguistic problems of EFL teachers, for example, the grammatical, lexical, semantics and mechanics errors documented in this study have led the present researchers to concur with Mitchell and Myles' (2004) argument. The scholars argued that the logical problem of language learning is caused by teachers' messy and fragmentary proficiency, making abstract concepts based on less proficiency and inappropriate usage of language skills that might affect the quality of their students' language proficiency.

Boldly speaking, teachers sometimes make the same error that their students make; they are not better than their students. With regard to this, Richards (2010) argues that English language teachers' proficiency is the most important skill among the dimensions of expertise in language teaching. However, the targeted teachers have failed to be good models and to maintain error-reduced use of the target language in the classroom.

The current researchers have embarked on teachers' errors on the grounds of informal observation and discovered that the subjects made many types of intralanguage errors like grammatical: subject-verb agreement, number, sentence structure, run-on and double negation errors; lexical: article, pronoun, preposition, adjective and pronunciation errors, semantics: word choice and word meaning errors; mechanics: spelling, capitalization and punctuation errors.

In their survey of similar literature, the current researchers could come across language education researchers (Owu-Ewie and Lomotey, 2016; Collins, 2007; Kim, 2001; Bataineh, 2005 and many others) who conducted their studies on error analyses focused on ESL/EFL students' oral or written errors. Surprisingly, the errors their students made are almost similar to what the targeted teachers have made. In other words, the targeted teachers are not far better than the results of the above studies conducted on students. Language education researchers and practitioners thus agree that teachers' performing in an underdeveloped intralanguage tends to impose a large burden on the ESL/EFL learners language proficiency (Tavokoli and Foster, 2008).

The results of classroom observation, teachers' interview, dictation and teachers' written essays revealed that there are many sources of teachers' oral and written 


\section{Tamiru Olana and Zeleke Teshome}

errors. It is undeniable that teachers' own errors give them insight into the difficulties in language teaching and therefore let them consider that errors are indispensable in the learning-teaching process (Brown, 2007). However, the case with the targeted teachers is beyond tolerance.

The analysis of the data attributed sources of the teachers' written errors to the grammatical, lexical, semantics and mechanics errors made as intralingual errors. It indicated that only pronunciation errors were made due to interlingual transfer. The interlingual problem has been prevalent for the reason that the participants themselves did not learn English pronunciation especially at early school age. Therefore, their literacy skills in the first language, as they put it, have heavily affected their English learning and then teaching. As result, the English teachers used Afan Oromo as the instructional language to teach English language.

Therefore, the model of fluency in speaking and writing was absent. The lack of fluency input could lead the teachers' error from Afan Oromo to English. That is why Hilton (2007) argues that gaps in lexical and pronunciation knowledge can seriously affect spoken fluency. Hilton further points out that it is very hard for an individual to engage in the higher-level, strategic aspects of meaning communication if his/her working memory is saturated by non-automated, lower-level L2 processes. A corollary of this argument is that anyone who wishes to transfer a second language must learn the grammar and vocabulary of the language, and master its sounds (Fulcher, 2003).

Murdoch (1994) argues that language proficiency will always represent the bedrock of EFL teachers' professional confidence. Richards (2010) substantiates Murdoch's contention saying that competence is crucial to maintain fluent use of the target language during instructions in the target language. He elaborates it more reiterating that competence helps teachers provide examples of words and grammatical structures, give accurate explanations (e.g. of vocabulary, use appropriate classroom language), select target-language resources (e.g. newspapers, magazines, internet websites), monitor their own speech and writing for accuracy, give correct feedback on learner language and provide input at an appropriate level of difficulty. Undoubtedly, each of these target language competences is closely related to teachers' ability to speak the target language fluently and confidently in classroom.

Nevertheless, the targeted teachers' case is the opposite. The finding indicated that even though they are professionals in teaching English, they still make remarkable errors when they use the language that might affect their students' oral and written English language proficiency. As to the researchers view, there is no ground for professionals to write, for example, many school, you will losing your life and I will borrow you my pen relaxingly.

It can be argued that the students' perceived speaking problems and difficulties will have an impact on teachers when they actually start to teach. Cullen (1994) reminds us that inadequate command of spoken English undermines teachers' confidence in the classroom, affects their self-esteem and sense of professional status, and makes it difficult for them to follow even fairly straight forward teaching procedures such as asking questions on a text. Can we say the case is the former or the latter? If
Sci. Technol. Arts Res. J., Oct-Dec 2015, 4(4): 164-173

we assume the former is the case, it can be argued that the students' being not proficient in the language, by any case, cannot be a reason for the teachers for producing wrong utterances. If we consider the latter, i.e., an inadequate command of the target language as the main source of their lack of confidence, we can conclude that they need much training to have a practical knowledge.

Taye (2008) put it convincingly witnessing that a large number of recruits have joined in the profession of teaching English without adequate professional training. As he concluded, that is why Ethiopian schools today have many teachers of English who themselves are not markedly efficient in the language and thus could not produce students who are more efficient. Richards (2010) also reports that insufficient attention has been given to the issue of language proficiency in many teacherpreparation programmes. Following Richards' steps, the current researchers suggest that attention has to be given to language teachers' proficiency because it contributes much to the teaching skills and leads to enhanced confidence in the teaching ability and an adequate sense of professional legitimacy as well. If not, the study subjects' proficiency in the language will adversely deteriorate and consequently affect that of their students.

\section{CONCLUSIONS}

The various linguistic problems of EFL teachers in the targeted schools have led the present researchers to conclude that the logical problem of language learning is caused by teachers' fragmentary proficiency, and inappropriate usage of language skills that affected the quality of their students' language proficiency. Though it is mandatory for the targeted teachers to improve their language proficiency, they have failed to be good models and to maintain error-reduced use of the target language in the classroom. Thus, it could be concluded that such teachers impose a large burden on their learners' language proficiency unless immediate measures are taken. The analysis of the data attributed sources of the teachers' written errors to the grammatical, lexical, semantics and mechanics errors made as intralingual errors. The interlingual problem has been prevalent for the reason that the literacy skills in the first language have adversely affected their English learning and then teaching.

From the findings of the study, the researchers sought that the EFL teachers have made several productive skills errors which necessitates short and long term trainings and workshops in the areas that need enhancement. The researchers are also aware that over-emphasizing errors might discourage the language learning motivation of the target language user. Even so, as models, teachers are required to minimize their own errors through self learning to be able to confidently provide corrective feedbacks to their students whenever they make errors.

\section{Conflict of Interest}

Conflict of interest none declared.

\section{REFERENCES}

Bataineh, R.F. (2005). Jordanian undergraduate EFL students' errors in the use of the indefinite. Asian EFL Journal 7(1): 5 . 


\section{Tamiru Olana and Zeleke Teshome}

Borg, S. (2003). Teacher cognition in language teaching: a review of research on what language teachers think, know, believe, and do. Language Teaching 36(2): 81-109.

Breen, M. P., Hird, B., Milton, M., Oliver, R., and Thwaite, A. (2001). Making sense of language teaching: Teachers' principles and classroom practices. Applied Linguistics 22(4): 470-501.

Brown, H.D. (2007). Principles of language learning and teaching. New York: Pearson Education, Inc.

Collins, L. (2007). L1 differences and L2 similarities: Teaching verb tenses in English [Electronic version]. ELT Journal 61(4): 295-304.

Cullen, R. (1994). Incorporating a language improvement component in teacher training programmes. ELT Journal 48(2):162-172

Dulay, H.C., Burt, M.K. and Krashen, S.D. (1982). Language two. New York: Oxford University Press.

Ellis, R. (1994). The study of second language acquisition. London: Oxford University Press.

Freeman, D., and Johnson, K. (1998). Reconceptualizing the knowledge-base of language teacher education. TESOL Quarterly 32(3): 397-417.

Fulcher, G. (2003). Testing second language speaking. Pearson Education Limited.

Golombek, P. (1998). A study of language teachers' personal practical knowledge. TESOL Quarterly 32(3): 447-464.

Greenbaum, S. and Nelson, G. (2002). An Introduction to English Grammar. London: Longman.

Hilton, H. (2007). Review of Expertise in second language learning and teaching by Johnson, K. (Ed.). System, 35: 112-117.

Kim, S. (2001). An Error Analysis of college students' writing: Is that really Konglish? Studies in Modern Grammar 25: 159-174.

Krashen, S. (1985). The input hypothesis: Issues and implication. London and New York: Longman.

Laufer, B. (1997). The lexical plight in second language reading. In: J. Coady and T. Huckin. (Eds). Second language vocabulary acquisition, (pp. 20-34). Cambridge: Cambridge University Press.

Meijer P. Verloop, N. and Beijard, D. (2001). Similarities and differences in teachers' practical knowledge about teaching reading comprehension. Journal of Educational Research 94(3), 171-184.

Meijer, P.C., Verloop, N. and Beijard, D. (1999). Exploring language teachers' practical knowledge about teaching reading comprehension. Teaching and Teacher Education 15: 59-84.
Sci. Technol. Arts Res. J., Oct-Dec 2015, 4(4): 164-173

Mitchell, R. and Myles, F. (2004). Second language learning theories. (2nd ed.). London: Edward Arnold.

Moran, P. R. (1996). "I'm not typical": Stories of becoming .a Spanish teacher: In D. Freeman, 8 Richards (Eds.), Teacher learning in language teaching (pp. 125-153). New York: Cambridge University Press.

Murdoch, G. (1994). Language development provision in teacher training curricula. ELT Journal, 48(3), 253-259.

Nel, N. and Müller, H. (2010). The impact of teachers' limited English proficiency on English second language learners in South African schools. South African Journal of Education 30: 635-650.

Norrish, J. (1990) Language Learners and their Errors London: Macmillan Publisher Ltd.

Owu-Ewie, C. and Lomotey, C.F. (2016). L1 (Akan) interference errors in L2 (English) writing: the case of three junior high school students in Ghana. American Journal of Language and Literacy, 1(1): A1-A18.

Peacock, M. (2001). Pre-service ESL teachers' beliefs about second language learning: a longitudinal study. System 29: $177-195$

Richards, J. C. (2010). Competence and performance in language teaching. RELC Journal 41(2): 101-122.

Richards, J.C. and Lockhart, C. (1994). Reflective teaching in second language classrooms. USA: Cambridge University Press.

Selinker, L. (1974). 'Interlanguage'. In Richards, J. (Ed.). Error analysis: perspectives on second language acquisition, 31-54. Essex: Longman.

Taye Regasa (2008). English as a tool in quality education: a study of the role in the reading comprehension of first year students at the college of social sciences, Addis Ababa University. In: Proceedings of the national workshop on language, culture and development in Ethiopia: the Ethiopian chapter of OSSREA. Addis Ababa.

Tewolde Gebreyohannes (1988). A comparison of the listening abilities of junior secondary school students with the listening level required of them in their subject areas. Addis Ababa University, Unpublished MA Thesis.

Ulichny, P. (1996). What's in a methodology? In, Freeman, D. and Richards J. C. (Eds.), Teacher learning in language teaching (pp. 178-196). Cambridge: Cambridge University Press.

Yoseph Mekonnen (1990). A study of the classroom language of junior secondary school teachers of English II. Addis Ababa: Addis Ababa University Press. M.A. Thesis Mimeographed. 